\title{
AKUNTANSI FORENSIK DI INDONESIA
}

\author{
Oleh: \\ Yansen Siahaan \\ Dosen STIE Sultan Agung
}

\begin{abstract}
Abstraksi
Akuntansi forensik mencuat di Amerika ketika berhasil diterapkan untuk membantu penangkapan $\mathrm{Al}$ Capone, seorang mafia AS yang bermarkas di Chicago. Bisnis hitam Al Capone yang bergerak di bidang prostitusi, judi, dan penjualan alkohol berjalan mulus dengan menutup peluang adanya tindakan hukum atas dirinya dengan cara menyuap agen-agen Federal, polisi lokal, politisi, dan wartawan.

Di Indonesia akuntansi forensik mencuat berkat keberhasilan Pricewaterhouse Coopers salah satu Kantor Akuntan The Big Four dalam membongkar kasus Bank Bali. Ketika itu Indonesia sedang menjajaki kemungkinan untuk meminjam dana dari IMF dan World Bank untuk mengatasi krisis keuangan yang semakin parah. Temuan ADDP ini sungguh mencengangkan karena perbankan kita telah melakukan penggelembungan aset (overstatement) sebesar 28\%-75\% dan understatement kewajiban sebesar 3\%-33\%. Temuan window dressing ini segera membuat pasar Indonesia panik yang pada gilirannya berujung 16 bank swasta dilikuidasi. Terdapat pemberitaan yang bertubi-tubi mengenai penyuapan kepada oknum penegak hukum, oknum anggota Dewan Perwakilan Rakyat, oknum pimpinan pemerintah pusat dan daerah, oknum komisioner, dan lain sebagainya.
\end{abstract}

Kata kunci : Akuntansi Forensik

Abstract

Forensic accountancy in America when succeeding applied to assist the arrest of Al Capone, a ACE mafia which have station in Chicago. Black Business of Al Capone which is active in prostitution, gambling, and alcohol sale walk smoothly with closing opportunity of is existence of action punish for x'self by condensing Federal agent, local police, politician, and journalist.

In Indonesia forensic accountancy of blessing of efficacy of Pricewate rhouse Coopers one of Office of Accountant of The Big Four in unloading case of Bali Bank. At the time Indonesia is possibility to borrow the fund from IMF and World Bank to overcome the finance crisis which going worse. this Finding ADDP really nonplus because our banking have conducted the asset distension (overstatement) equal to $28 \%-75 \%$ and understatement obligation equal to 3\%-33\%. this finding Window dressing immediately make the market of panic Indonesia which in turn tip of 16 private bank liquidation. There are news which repeatedly hit the bribery to oknum enforcer punish the, oknum of Parliament member, oknum of head of central government and area, oknum commissioner, and others.

Keyword : Forensic Accountancy

\section{A. PENDAHULUAN DAN PEMBaHASAN \\ 1. Akuntansi Forensik}

Hopwood et al. (2008) mendefinisikan Akuntansi Forensik sebagai aplikasi keterampilan investigasi dan analitik yang bertujuan untuk memecahkan masalah-masalah keuangan melalui suatu cara yang sesuai dengan standar yang ditetapkan oleh pengadilan atau hukum. Investigasi dan analisis semacam ini dilakukan sesuai dengan standar yang ditetapkan oleh pengadilan atau hukum yang memiliki yurisdiksi yang kuat. Seorang akuntan forensik disamping dapat bertugas memberikan pendapat hukum dalam pengadilan (litigation), juga dapat berperan dalam bidang hukum diluar pengadilan (non litigation) misalnya dalam membantu merumuskan alternatif penyelesaian perkara dalam sengketa perumusan perhitungan ganti rugi dan upaya menghitung dampak pemutusan pelanggaran kontrak. Orang yang bekerja di lembaga keuangan atau manajer dari suatu organisasi atau unit kerja juga perlu memahami tentang akuntansi forensik ini, manakala ia harus mengetahui apa yang ada di balik laporan keuangan debitur, apa yang ada dibalik laporan hasil analisis yang disajikan. Hal ini tentu saja, dimaksudkan agar segala sesuatu dapat dilakukan pendeteksian sejak dini, guna mencegah permasalahan menjadi melebar dan sulit diatasi.

Perbedaaan utama akuntansi forensik dengan akuntansi maupun audit umum terletak pada kerangka pemikirannya (mindset). Kalau akuntansi forensik lebih menekankan pada keganjilan, ketidakteraturan (oddness and irregularities) dan pola tindakan (pattern of conduct), maka audit umum lebih menekankan pada kesalahan (errors) dan keteledoran (ommisions). Teknik audit dalam akuntansi forensik menekankan pada teknik audit yang biasa diterapkan dalam audit umum seperti inspeksi (inspection), konfirmasi (confirming), vouching, tracing, prosedur analitis, wawancara, penghitungan (counting), melakukan ulang 
(reperforming), pengamatan (observation) dan CAAT (Computer Assisted Audit Techniques).

\section{Tugas Akuntan Forensik}

Akuntan forensik bertugas memberikan pendapat hukum dalam pengadilan (litigation). Disamping tugas akuntan forensik untuk memberikan pendapat hukum dalam pengadilan, akuntan forensik berperan juga dalam bidang hukum diluar pengadilan (non litigation) misalnya dalam membantu merumuskan alternatif penyelesaian perkara dalam sengketa, perumusan perhitungan ganti rugi dan upaya menghitung dampak pemutusan / pelanggaran kontrak.

\section{Keahlian Akuntan Forensik}

Akuntan forensik sering memanfaatkan keahlian akuntansinya dalam litigasi. Penghitungan kerugian dalam kasus-kasus seperti cidera yang diderita oleh seseorang, liabilitas produk, sengketa kontrak, dan kekayaan intelektual serta pengungkapan aset-aset yang tersembunyi dalam kasus hukum perkawinan yang kompleks. Jenis-jenis jasa ini dapat meningkat ketika akuntan forensik diundang sebagai saksi ahli. Akuntan forensik menggunakan keahlian yang unik dalam menjalankan tugas-tugas seperti menentukan apakah sebuah perusahaan telah melakukan mis-interpretasi terhadap catatan laporan keuangan, apakah telah terjadi fraud, dan apakah telah terjadi laporan keuangan yang berlebih-lebihan (window dressing) atau upaya menstabilkan laba (Income smoothing) pada sebuah perusahaan. Dengan demikian keahlian seorang akuntan forensik dapat digunakan dalam menyelidiki berbagai jenis kecurangan (fraud) di perusahaan maupun di pemerintahan. harus:

Untuk menjadi seorang Akuntan Forensik, ia

a. Memiliki pengetahuan dasar akuntansi dan audit yang kuat

b. Sebuah pengetahuan yang mendalam tentang laporan keuangan, dan kemampuan untuk melakukan analisa kritis atas laporan tersebut. Keterampilan ini membantu akuntan forensik menemukan pola abnormal transaksi baik dalam sumber maupun jumlahnya. Dia perlu memahami teknik audit yang biasa diterapkan dalam audit umum seperti inspeksi fisik (inspection), konfirmasi (confirming), vouching, tracing, prosedur analitis, wawancara, kuesiner, penghitungan (counting), melakukan ulang (reperforming). pengamatan (observation) dan CAAT

c. Pengenalan perilaku manusia dan organisasi

d. Pengetahuan tentang psikologi, dalam rangka untuk memahami latar belakang perilaku kriminal dan menyiapkan program pencegahan penipuan yang mendorong dan memotivasi karyawan.

e. Pengetahuan tentang hukum dan peraturan (bukti keuangan dan bukti hukum). f. Pemahaman umum atas hukum pidana, perdata, sistem hukum dan prosedur pengadilan.

g. Pengetahuan tentang kriminologi dan viktimologi

h. Sebuah ketelitian tentang pemahaman skema penipuan, namun tidak terbatas pada pengelapan aset termasuk, pencucian uang, penyuapan dan korupsi

i. Pemahaman terhadap struktur pengendalian intern.

j. Keahlian di ilmu komputer dan sistem jaringan. Keterampilan ini membantu akuntan forensik melakukan penyelidikan di era e-banking dan sistem komputerisasi akuntansi.

k. Kemampuan komunikasi, yang membantu dalam penyebaran informasi tentang kebijakan etis perusahaan dan membantu akuntan forensik melakukan wawancara dan diperlukan memperoleh informasi yang sangat penting.

Akuntansi forensik biasanya fokus pada areaarea tertentu, misalnya penjualan, pembelian, penerimaan dan pengeluaran uang tertentu. Agar dapat membongkar terjadinya kecurangan maka seorang akuntan forensik harus memiliki pengetahuan dasar akuntansi dan audit yang kuat, pengenalan perilaku manusia dan organisasi, pengetahuan tentang aspek yang mendorong terjadinya kecurangan, pengetahuan tentang hukum dan peraturan, pengetahuan tentang kriminologi dan viktimologi, dan pemahaman terhadap pengendalian internal.

Objek audit forensik adalah informasi keuangan yang diduga mengandung unsur penyimpangan. Penyimpangan bisa berupa tindakan merugikan keuangan seseorang, perusahaan, atau bahkan negara. Temuan audit dari hasil pemeriksaan ini bisa dijadikan salah satu alat bukti bagi penyidik, pengacara, atau jaksa untuk memutuskan suatu kasus hukum perdata. Tidak menutup kemungkinan hasil audit juga akan memberikan bukti baru untuk tindakan yang menyangkut hukum pidana. Dalam kasus semacam ini, auditor dituntut harus benarbenar independen. Meskipun penugasan audit diberikan oleh salah satu pihak yang bersengketa, independensi auditor harus tetap dijaga. Auditor tidak boleh memihak pada siapa-siapa. Setiap prosedur audit, kertas kerja, dan pernyataan auditor adalah alat bukti yang menghasilkan konskuensi hukum pada pihak yang bersengketa. Audit forensik merupakan salah satu bagian dari Special Audit. Audit forensik lebih tepat digunakan jika sudah bersinggungan dengan bidang hukum. Sementara hasil audit dapat, tetapi tidak harus, digunakan dalam proses pengadilan atau bentuk penyelesaian hukum lainnya. Dalam penerapannya audit forensik memang banyak bersinggungan dengan hukum. Pengungkapan kasus Bank Bali ternyata melalui keberhasilan akuntansi forensik. Auditor Pricewaterhouse Coopers berhasil menunjukkan aliran dana yang bersumber dari pencairan dana penjaminan Bank Bali. Mengingat audit forensik 
selalu bersinggungan dengan hukum, dalam pengumpulan bukti audit seorang auditor forensik harus memahami masalah hukum pembuktian. Bukti yang dikumpulkan harus dapat diterima di pengadilan. Cara perolehan bukti pun tidak boleh melanggar hukum, karena dapat berakibat ditolaknya alat bukti secara hukum. Teknik dan Prosedur audit harus sesuai dengan standar profesi, sekaligus hukum pidana, perdata, atau produk hukum lainnya.

Seorang akuntan forensik yang sukses mempunyai kompetensi dalam mengumpulkan fakta-fakta dari berbagai saksi secara fair, netral, sah, dan akurat, serta mampu melaporkan fakta-fakta itu secara akurat dan lengkap. Teknik wawancara, pengujian laporan keuangan, pengumpulan bukti, pemahaman peraturan dan perundang-undangan yang terkait, serta prosedur-prosedur lain yang diperlukan selama tidak melanggar kode etik akuntan/auditor dan undang-undang. Tidak semua akuntan memiliki kemampuan investigatif layaknya detektif ataupun penyidik, tentu saja harus tetap dalam koridor keuangan dan laporan keuangan. Akuntan forensik adalah gabungan dari kompetensi pengacara, akuntan, kriminolog, dan investigator.

\section{Peran BPK}

Akuntansi forensik sebenarnya telah dipraktekkan di Indonesia. Praktek ini tumbuh pesat, tak lama setelah terjadi krisis keuangan tahun 1977. Akuntansi forensik dilaksanakan oleh berbagai lembaga seperti Badan Pemeriksa Keuangan (BPK), Komisi Pemberantasan Korupsi (KPK), Pusat Pelaporan dan Analisis Transaksi Keuangan (PPATK), Badan Pengawasan Keuangan dan Pembangunan (BPKP), Bank Dunia (untuk proyekproyek pinjamannya), dan kantor-kantor akuntan publik (KAP) di Indonesia. Perkembangan positif dalam pemberantasan korupsi di Indonesia membuat Badan Pemeriksa Keuangan (BPK) yang selama era orde baru seolah dikerdilkan menjadi percaya diri kembali, dengan terbitnya Undang-Undang No 17 Tahun 2003 Tentang Keuangan Negara yang menegaskan kewenangan BPK sebagai Pemeriksa Keuangan Negara dan kemudian di dukung UndangUndang No 15 Tahun 2006 yang memberikan kemandirian dalam pemeriksaan Keuangan Negara baik yang tidak dipisahkan maupun yang dipisahkan seperti BUMN dan BUMD sekaligus penentu jumlah kerugian Negara. BPK merupakan badan yang tidak tunduk kepada pemerintah sehingga diharapkan dapat melakukan pemeriksaannya secara independen. Sebenarnya BPK sebagai Pemeriksa Keuangan Negara memiliki prestasi yang layak diapresiasi dalam melakukan audit forensik. Tetapi BPK perlu instropeksi untuk menjadi frontliner (garda terdepan) dalam pemberantasan korupsi di Indonesia, dengan cara meningkatkan metodologi auditnya dan meningkatkan kinerja pegawainya dalam melakukan pemeriksaan keuangan negara termasuk didalamnya keahlian tehnis dalam mendeteksi kecurangan ( fraud).

\section{Peran IAI Sebagai Penghimpun Standar (Standard Setter) dan Perguruan Tinggi sebagai Penyelenggara Pendidikan. \\ Di Indonesia perkembangan ilmu akuntansi} forensik ini masih infant (orok), sangat jauh ketinggalan bila dibandingkan dengan negara Australia yang sedang menyusun Standar Akuntansi Forensik. Kanada dan Amerika Serikat sudah memiliki standar yang baku. Belum adanya standar yang memadai membuat ilmu ini kurang begitu dikenal. Seorang akuntan forensik, selain menguasai akuntansi dan audit juga harus menguasai bidang yang berkaitan dengan kejahatan keuangan ,hukum, psikologi, sosiologi, antropologi, viktimologi, kriminologi, dan lain-lain. Singkatnya, Akuntan forensik harus memiliki "multitalenta". Beberapa kalangan meramalkan perkembangan profesi ini kedepan akan lebih pesat. Oleh sebab itu IAI sudah saatnya menyusun Standar Akuntansi Forensik secara rinci sebagai aturan baku. Demikian halnya penyelenggara pendidikan terkait, sudah saatnya membekali lulusan dengan kompetensi akuntansi forensik dengan menawarkan sebagai salah satu mata kuliah dalam kurikulumnya atau sebagai salah satu program studi sehingga diharapkan dapat menghasilkan akuntan forensik yang handal dan profesional.

\section{B. KESIMPULAN}

1. Akuntansi Forensik adalah aplikasi keterampilan investigasi dan analitik yang bertujuan untuk memecahkan masalah-masalah keuangan melalui cara-cara yang sesuai dengan standar yang ditetapkan oleh pengadilan atau hukum

2. Investigasi dan analisis dilakukan harus sesuai dengan standar yang ditetapkan oleh pengadilan atau hukum yang memiliki yurisdiksi yang kuat.

3. Akuntansi forensik dapat dikembangkan sebagai strategi preventif, detektif dan persuasif melalui penerapan prosedur audit forensik dan audit investigatif yang bersifat pendukung (litigation support) untuk menghasilkan temuan dan bukti yang dapat digunakan dalam proses pengambilan putusan di pengadilan.

4. Akuntan forensik bertugas memberikan pendapat hukum dalam pengadilan (litigation), dan juga bisa berperan dalam bidang hukum diluar pengadilan (non litigasi). misalnya dalam membantu merumuskan alternatif penyelesaian perkara dalam sengketa, perumusan perhitungan ganti rugi dan upaya menghitung dampak pemutusan / pelanggaran kontrak. 
5. Prosedur audit yang biasa diterapkan dalam audit umum seperti inspeksi fisik, konfirmasi, memeriksa dokumen (vouching dan tracing), prosedur analitis, meminta penjelasan tertulis atau lisan (wawancara dan kuesiner), penghitungan (counting) dan melakukan ulang (reperforming) dan pengamatan (observation) pada dasarnya dapat digunakan untuk audit forensik.

6. IAI sudah saatnya menyusun Standar Akuntansi Forensik secara rinci sebagai aturan baku.

7. Penyelenggara pendidikan terkait sudah waktunya membekali lulusan dengan kompetensi akuntansi forensik dengan menawarkan mata kuliah ini dalam kurikulumnya sehingga institusi diharapkan dapat menghasilkan tenaga akuntansi forensik dan audit forensik yang handal dan profesional.

\section{DAFTAR PUSTAKA}

Tuannakota, Theodorus M, 2010, Akuntansi Forensik dan Audit Investigasi, Jakarta: Salemba

Wahito, M Najib, 2012, Mengenal Akuntansi Forensik ., detikNews 